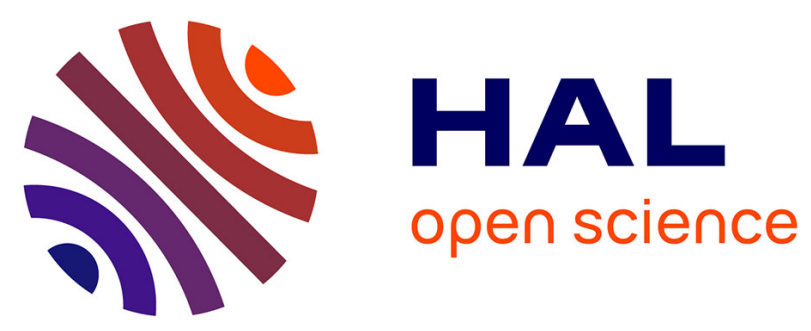

\title{
Molecular characterization of 1q44 microdeletion in 11 patients reveals three candidate genes for intellectual disability and seizures.
}

Gaelle Thierry, Claire Bénéteau, Olivier Pichon, Elisabeth Flori, Bertrand Isidor, Françoise Popelard, Marie-Ange Delrue, Laetitia Duboscq-Bidot, Ann-Charlotte Thuresson, Bregje van Bon, et al.

\section{To cite this version:}

Gaelle Thierry, Claire Bénéteau, Olivier Pichon, Elisabeth Flori, Bertrand Isidor, et al.. Molecular characterization of 1q44 microdeletion in 11 patients reveals three candidate genes for intellectual disability and seizures.. American Journal of Medical Genetics Part A, 2012, 158A (7), pp.1633-40. 10.1002/ajmg.a.35423 . inserm-00706725

\section{HAL Id: inserm-00706725 https://www.hal.inserm.fr/inserm-00706725}

Submitted on 12 Jul 2012

HAL is a multi-disciplinary open access archive for the deposit and dissemination of scientific research documents, whether they are published or not. The documents may come from teaching and research institutions in France or abroad, or from public or private research centers.
L'archive ouverte pluridisciplinaire HAL, est destinée au dépôt et à la diffusion de documents scientifiques de niveau recherche, publiés ou non, émanant des établissements d'enseignement et de recherche français ou étrangers, des laboratoires publics ou privés. 
1Molecular characterization of $1 \mathrm{q} 44$ microdeletion in eleven patients reveals three 2candidate genes for intellectual disability and seizures

3

4Gaelle Thierry, ${ }^{1,18}$ Claire Bénéteau, ${ }^{1,18}$ Olivier Pichon, ${ }^{1}$ Elisabeth Flori, ${ }^{2}$ Bertrand Isidor, ${ }^{1}$ 5Françoise Popelard, ${ }^{3}$ Marie-Ange Delrue, ${ }^{4}$ Laetitia Duboscq-Bidot, ${ }^{5}$ Ann-Charlotte 6Thuresson, ${ }^{6}$ Bregje WM van Bon, ${ }^{7}$ Dorothée Cailley, ${ }^{4}$ Caroline Rooryck, ${ }^{4}$ Agathe Paubel, ${ }^{8}$ 7Corinne Metay, ${ }^{9}$ Anne Dusser, ${ }^{10}$ Laurent Pasquier, ${ }^{11}$ Mylène Béri, ${ }^{12}$ Céline Bonnet, ${ }^{12}$ Sylvie 8Jaillard, ${ }^{13}$ Christèle Dubourg, ${ }^{14,15}$ Bassim Tou, ${ }^{16}$ Marie-Pierre Quéré, ${ }^{17}$ Cecilia Soussi-Zander, ${ }^{6}$ 9Annick Toutain, ${ }^{8}$ Didier Lacombe, ${ }^{4}$ Benoit Arveiler, ${ }^{4}$ Bert BA de Vries, ${ }^{7}$ Philippe Jonveaux, ${ }^{12}$ 10Albert David, ${ }^{1}$ Cédric Le Caignec ${ }^{1,5, *}$

11

$12^{1} \mathrm{CHU}$ Nantes, Service de Génétique Médicale, Nantes, France

13²Service de Cytogénétique, Hôpital de Hautepierre, Strasbourg, France

$14^{3}$ Service de Pédiatrie, Centre Hospitalier Jean Monnet, Epinal, France

$15^{4}$ Service de Génétique Médicale, Hôpital Pellegrin; Université de Bordeaux, Maladies Rares : 16Génétique et Métabolisme (MRGM), EA 4576, Bordeaux, France

1755Inserm, UMR_S915, l'institut du thorax, Nantes, France

$18^{6}$ Department of Immunology, Genetics and Pathology, Uppsala University, Uppsala, Sweden $19^{7}$ Department of Human Genetics, Radboud University Nijmegen Medical Center, Nijmegen, 20The Netherlands

$21{ }^{8}$ Service de Génétique Médicale, CHU, Tours, France

$22^{9}$ Plateforme Génétique Constitutionnelle CGH array, Hôpital Henri Mondor, Créteil, France $23{ }^{10}$ Service de Neurologie Pédiatrique, CHU Bicêtre, Le Kremlin Bicêtre, France $24{ }^{11}$ Service de Génétique Médicale, CLAD Ouest, Hôpital Sud, CHU Rennes, Rennes, France $25^{12}$ Laboratoire de génétique, CHU, Nancy, France 
$1{ }^{13}$ Laboratoire de Cytogénétique, CHU Pontchaillou, Rennes Cedex, France

$2^{14}$ Institut de Génétique et Développement, CNRS UMR 6061, Université de Rennes 1, IFR140 3GFAS, Faculté de Médecine, Rennes, France

$4{ }^{15}$ Laboratoire de Génétique Moléculaire, CHU Pontchaillou, Rennes, France

$5^{16}$ Laboratoire de Génétique Moléculaire, Pharmacogénétique et Hormonologie, Hôpital 6Universitaire de Bicêtre, Secteur Paul Broca, Le Kremlin Bicêtre, France

$7{ }^{17} \mathrm{CHU}$ Nantes, Service de radiologie pédiatrique, Nantes, France

$8^{18}$ Both authors contributed equally to this work

9

10

11 * Correspondence to: Cédric Le Caignec, MD, PhD, Service de Génétique Médicale, CHU, 9, 12quai Moncousu 44093 Nantes, France, Tél.: +33 2400842 84, Fax: +33 2400839 43, E13mail: cedric.lecaignec@chu-nantes.fr

14

15Key Words: 1q44, deletion, chromosome, HNRNPU, FAM36A, ncRNA, intellectual 16disability, corpus callosum, seizure

17 


\section{ABSTRACT}

2

3Patients with a submicroscopic deletion at 1q43q44 present with intellectual disability (ID), 4microcephaly, craniofacial anomalies, seizures, limb anomalies and corpus callosum 5abnormalities. However, the precise relationship between most of deleted genes and the 6clinical features in these patients still remains unclear. We studied 11 unrelated patients with $71 \mathrm{q} 44$ microdeletion. We showed that the deletions occurred de novo in all patients for whom 8both parents' DNA was available (10/11). All patients presented with moderate to severe ID, 9seizures and non-specific craniofacial anomalies. By oligoarray-based comparative genomic 10hybridization $(\mathrm{aCGH})$ covering the 1q44 region at a high resolution, we obtained a critical 11deleted region containing two coding genes - HNRNPU and FAM36A - and one non-coding 12gene - NCRNA00201. All three genes were expressed in different normal human tissues, 13including in human brain, with highest expression levels in the cerebellum. Mutational 14screening of the HNRNPU and FAM36A genes in 191 patients with unexplained isolated ID 15 did not reveal any deleterious mutations while the NCRNA00201 non-coding gene was not 16analyzed. Nine of the 11 patients did not present with microcephaly or corpus callosum 17abnormalities and carried a small deletion containing HNRNPU, FAM36A and NCRNA00201 18but not $A K T 3$ and $Z N F 238$, two centromeric genes. These results suggest that $H N R N P U$, $19 F A M 36 A$ and NCRNA00201 are not major genes for microcephaly and corpus callosum 20abnormalities but are good candidates for ID and seizures. 


\section{INTRODUCTION}

3

4 Intellectual disability (ID) represents the most frequent cause of severe handicap in 5 children and one of the main reasons for referral in clinical genetic practices. Causes of ID are 6extremely heterogeneous and can result from chromosomal rearrangements, monogenic 7disorders, and/or environmental factors. Despite clinical examination and extensive 8 complementary investigations, no etiology is identified in up to 50 . of the patients with 9moderate to severe ID [Chelly et al., 2006], hampering accurate genetic counseling and 10clinical follow-up. During these last years, the advent of high-resolution microarray 11techniques allowed for the detection of increasingly smaller rearrangements in patients with 12ID. The method has greatly facilitated deciphering chromosomal disorders, enabling better 13genotype - phenotype correlations and thus the identification of new genes responsible for ID. 14 A number of chromosomal regions scattered through the human genome are deleted in 15patients with ID, among them the 1q43q44 region. This deletion syndrome was first described 16by De Vries et al. [2001]. Patients present with ID, microcephaly, craniofacial anomalies, 17seizures, limb anomalies and corpus callosum abnormalities. However, the precise 18relationship between most of deleted genes and the clinical features in these patients still 19remains unclear. Three studies have each proposed a different smallest region of overlap 20(SRP) for corpus callosum abnormalities. A first critical deleted region described by Boland 21et al. [2007] was $1.25 \mathrm{Mb}$ in size and contained two candidate genes: AKT3 and ZNF238. 22Next, van Bon et al. [2008] identified a second distinct critical region of $0.36 \mathrm{Mb}$ in size, 23more telomeric than the first one, and containing four different candidate genes: Clorf100, 24ADSS, Clorf101 and PNAS-4. Caliebe et al. [2010] proposed a third interval of $0.44 \mathrm{Mb}$, 25 which is more telomeric than the other two, and which contained the HNRNPU gene. Finally, 
1 the combined data from two recent studies, a first one performed on 22 patients [Ballif et al., 22011] and a second one based on 7 patients [Nagamani et al., 2012] sharing 1q43q44 3microdeletion, proposed three distinct SRO with different sizes implicated in corpus callosum 4abnormalities (75 $\mathrm{kb}$ in size, including ZNF238), microcephaly (133 kb in size, including $5 A K T 3)$ or seizures (100 kb in size, including HNRNPU, FAM36A and NCRNA00201 6previously referred as C1ORF199). We focused our study on 11 unrelated patients with ID 7and seizures carrying a 1q44 interstitial microdeletion. We refined the SRO for ID and 8seizures to three genes and explored each of these three genes to highlight their potential role 9played in the phenotype.

10

11PATIENTS AND METHODS

12

13Patients

14

15 We studied 11 unrelated patients (eight females and three males) with a 1q44 16microdeletion. The non-specific craniofacial anomalies are presented in Figure 1 and clinical 17 features are summarized in Table I. The patients originated from Europe (France, Sweden, 18Finland, Monaco, The Netherlands and Germany) and Senegal. No consanguinity or familial 19 genetic history was noted in the families. The pregnancies were uneventful.

20 All patients presented with moderate to severe ID, predominantly on verbal learning 21disabilities. Milestones were delayed in all patients: sitting unsupported ranged from 6 months 22to 3 years of age, walking unsupported from 2 to 5 years of age, and severe speech delay (6 23patients aged from 4 years and 6 months to 17 years had no expressive speech and one patient 24had severe speech delay and phonetic disorders). Neurological examination revealed axial 25hypotonia in four cases. Five patients presented with stereotyped movements of the hands 
1 with voluntary use of their hands conserved and were suspected for Rett syndrome. Two 2patients had sleep disturbances, of which one was treated with Melatonin with good results. 3Four patients had autistic features and/or attention deficit disorder.

4 Seizures were observed in all patients. The age of the first seizure ranged from 6 5months to 2.5 years of age. Different types of seizures were observed: absences, generalized, 6tonic-clonic seizures and Lennox-Gastaut syndrome. Epilepsy required treatment in most 7patients, no pharmaco-resistant epilepsy was noted except for patient 3. Two patients 8developed status epilepticus history. Magnetic resonance imaging (MRI) revealed agenesis of 9corpus callosum in patient 2 . The corpus callosum was normal in all other patients. MRI 10revealed other brain abnormalities: delayed myelinisation, generalized or subcortical atrophy, 11 micropolygyria, moderate ventricular dilatation and moderate cerebellar hypoplasia. Only two 12patients (\#1 and \# 2) among the eleven presented with microcephaly. Both patients carried the 13larger deletions including the $A K T 3$ gene. This finding is consistent with other recent reports 14suggesting that AKT3 is a strong candidate gene for microcephaly [Ballif et al., 2011; 15Nagamani et al., 2012].

16 Six patients developed general obesity during childhood (BMI around +4 SD, obesity 17grade 2). Five patients had short stature (heights between -2.5 and -3 SD). Six patients had 18 small hands and broad, short and/or small feet with small toes. Craniofacial anomalies were 19 present in all patients, but did not lead to a characteristic facial dysmorphism. Hypertelorism 20(4/10), strabismus (4/9), bulbous nose (3/10), long and flat philtrum (5/10) and abnormal ears 21(4/10) were frequently observed.

22 Occasionally, some malformations were observed: unilateral renal agenesis, congenital 23heart defects (atrial septal defect and pulmonary stenosis), and some skeletal anomalies (a 24butterfly vertebrae, a scoliosis). 


\section{Cytogenetic and aCGH studies}

2

3 Informed consent for genetic analyses was obtained from parents of the patients 4according to local ethical guidelines. Karyotyping based on R or G banding was performed 5using standard methods on metaphase spreads from peripheral blood of the patients. Genomic 6DNA was extracted from peripheral blood using standard protocols. Molecular karyotyping of 7the 11 patients was initially conducted using different array platforms according to 8manufacturers' instructions. Subsequently, we used a custom targeted 60K Agilent array to 9fine map the breakpoints of the deletions with a median resolution of $240 \mathrm{bp}$. Custom arrays 10comprising 25,021 probes covered a $6 \mathrm{Mb}$ in the 1q44 region including the HNRNPU, $11 F A M 36 A$ and NCRNA00201 genes. Arrays were analyzed with a Agilent scanner and the 12Feature Extraction software (v. 10.5.1.1). Graphical overview was obtained using the 13Genomic Workbench software (v.5.0). Deletion breakpoints were mapped to the UCSC 14genome browser, hg19. A second independent method (fluorescence in situ hybridization 15(FISH) with different probes, qPCR or MLPA) was used to confirm the deletions and for 16parental inheritance in patients for whom DNA was available. Three individuals of Yoruba 17Nigerian origin from the HapMap Project were obtained from the Coriell Institute [IHMC, $182005]$ and were also analyzed using the custom $60 \mathrm{~K}$ array.

19

\section{0mRNA expression studies}

21

22 We performed expression analyses for HNRNPU, FAM36A and NCRNA00201 using 23total RNA extracted from different human tissues (primer sequences available upon request). 24RNAs were obtained from adult brain, heart, kidney, liver, cerebellum tissues and from fetal 25brain tissue (Clontech). Real time quantitative reverse transcription PCR (RT-qPCR) was 
1performed using the $\Delta \Delta \mathrm{Ct}$ method [Livak et al., 2001] to assess expression level of the three 2target genes - HNRNPU, FAM36A and NCRNA00201 - relative to the expression level of the $3 \beta$-actin (ACTB) and cyclophilin E (PPIE) housekeeping genes. For a given target gene, the $4 \Delta \mathrm{Ct}$ of each tissue was compared to the median of the $\Delta \mathrm{Ct}$ of the 6 tissues analyzed.

5

\section{Mutation screening}

7

8 The coding exons and the exon-intron boundaries of the HNRNPU and FAM36A genes 9were sequenced in 9/11 patients with a 1q44 deletion using the Sanger technology and run on 10ABI 3130 (primer sequences available upon request). A series of 191 patients with 11unexplained isolated ID were used to search for point mutations in $H N R N P U$ and FAM36A. 12Standard karyotyping was normal in all 191 patients. In addition, molecular karyotyping 13performed with a 44K Agilent array was normal in 112/191 patients while the other patients 14were not analyzed. PCR amplifications followed by high-resolution melting method (HRM) 15were performed to screen HNRNPU (exons 2-14). PCR amplifications followed by Sanger 16sequencing were performed to screen the 5' half of exon 1 of $H N R N P U$ and the four exons of $17 F A M 36 A$. We failed to sequence the 3' half of exon 1 of $H N R N P U$.

18

19RESULTS

20

\section{Cytogenetic and aCGH results}

22

23 Following normal standard karyotyping, a 1q44 microdeletion was identified in 11 24patients with moderate to severe ID, craniofacial anomalies and seizures using different high25resolution array platforms. No other pathogenic genomic imbalances were identified in the 
1patients. All deletions were confirmed by FISH, qPCR or MLPA. Parental analyses 2demonstrated de novo deletions in all families when both parents' DNA was available. Using 3a custom targeted aCGH method, we showed that the sizes of the deletions were variable, 4ranging from $626 \mathrm{~Kb}$ to $2.57 \mathrm{Mb}$ (supplementary Table I). The size of the SRO was $188 \mathrm{~Kb}$ 5and encompassed four genes: HNRNPU, FAM36A, NCRNA00201, and EFCAB2. The 6identification of a normal individual with a partial deletion of the EFCAB2 gene led us to 7 consider as unlikely causative this gene as a cause of ID, thus refining the SRO to three genes: 8HNRNPU, FAM36A, and NCRNA00201 (Fig. 2). In a previous study, Matsuzaki et al. [2009] 9identified a deletion involving $H N R N P U$ in three HAPMAP individuals of Yoruba Nigerian 10origin. In contrast, we obtained normal results with our targeted $60 \mathrm{~K}$ array, excluding a 11deletion in the 1q44 region in these individuals and, thus, demonstrating that the deletions 12identified by Matsuzaki et al. [2009] were false positive results. Therefore, no deletion 13involving one of these three genes located in this $1 \mathrm{q} 44$ region has been observed within 14individuals of the general population (www.tcag.org).

15

\section{6mRNA expression studies}

17

18 We showed that HNRNPU, FAM36A and NCRNA00201 were expressed in 6 different 19 tissues (adult brain, heart, kidney, liver, cerebellum tissues and fetal brain tissue), with the 20strongest expression in the cerebellum (Fig. 3). The highest level of transcripts was obtained 21 for NCRNA00201 in the cerebellum. As the strongest expression of theses three genes were 22detected in cerebellum, we analyzed the expression of two control genes: SULF1 and 23SLCO5A1. We obtained low expression levels in the cerebellum compared to other tissues for

24these genes, thus excluding a potential bias in our sample of RNA extracted from the 25cerebellum (data not shown). 


\section{Mutation screening}

3

4 Direct sequencing of $H N R N P U$ and FAM36A did not reveal any deleterious point 5mutations in the remaining allele of the patients with a 1q44 deletion, rendering unlikely a 6recessive mode of inheritance. Neither did we detect any deleterious mutations in these two 7 genes in our series of 191 patients with unexplained ID. Two identified exonic variants in 8HNRNPU (exon 6 c.1215G $>$ A, synonymous; exon 14 c.2437C $>\mathrm{G}$, p.Gln813Glu) and one in 9FAM36A (exon 4 c.340G $>$ A, p.Gly114Ser) were predicted to be benign using the PolyPhen 10software.

11

\section{DISCUSSION}

13

14 In this study, all eleven patients carrying a 1q44 microdeletion presented with 15moderate to severe ID, seizures and non-specific craniofacial anomalies, corresponding to a 16non-recognizable phenotype with ID. The aCGH data allowed us to fine map a SRO for 17 moderate to severe ID and seizures. However, since other reports described patients with 18deletions in the 1q43q44 bands that did not include the SRO defined in the present study, 19there may be a number of additional genes that when haploinsufficient can cause ID in these 20patients.

21 Two recent studies, a first one performed on 22 patients [Ballif et al., 2011] and a 22second one based on 7 patients [Nagamani et al., 2012] sharing 1q43q44 microdeletion, 23clarified the phenotype/genotype correlation and proposed three distinct SRO. The first SRO 24encompassing ZNF238 was associated with corpus callosum abnormalities, the second SRO 25including AKT3 caused microcephaly in most patients while the third SRO containing the 
1three genes FAM36A, HNRNPU and NCRNA00201 was associated with seizures. In our 2study, 2/11 patients (\#1 and \# 2) carried a deletion of both ZNF238 and AKT3. Both patients 3 presented with microcephaly which was consistent with a role of AKT3 in microcephaly. Only 4patient 2 presented with a corpus callosum agenesis. Incomplete penetrance associated with 5deletion of ZNF238 could explain the lack of corpus callosum abnormality in patient 1 . 6Finally, the third previously published SRO associated with seizures in Ballif et al. [2011] 7overlapped with our $188 \mathrm{~Kb}$ SRO associated with ID, seizures and craniofacial anomalies.

8 FAM36A encodes a hypothetical protein and, to date, its biological role is still 9unknown.

$10 H N R N P U$ is a protein-coding gene comprising 14 exons, which are highly conserved 11during evolution. The HNRNPU protein is able to bind RNAs and mediates different aspects 12of their metabolism and transport [Dreyfuss et al., 2002; Krecic and Swanson, 1999]. Mice 13with a homozygous hypomorphic mutation in $H N R N P U$ are severely retarded in both growth 14and development indicating that this gene is essential for embryonic development [Roshon et 15al., 2005]. Although ubiquitously expressed, we detected the highest expression level for $16 H N R N P U$ in human cerebellum, a tissue which plays an essential role in cognition. 17Interestingly, $H N R N P U$ is involved in later stages of differentiation of cerebellar neurons via 18the regulation of DNA topoisomerase II $\beta$ activity [Kawano et al., 2010]. Thus, 19haploinsufficiency for $H N R N P U$ may lead to ID in our patients, even in the absence of 20clinical cerebellar anomalies. $C D H 15$ is such an example where a gene is strongly expressed 21 in the cerebellum and mutations for which are associated with ID with no features of 22cerebellar dysfunction [Bhalla et al., 2008].

23 The third gene within the SRO of our study, NCRNA00201, encodes a long non24coding RNA (lncRNA). The majority of lncRNA has very high levels of expression in the 25 central nervous system in a cell-type specific manner, of which some have already been 
1implicated in neurological and developmental disorders [for a review Qureshi et al., 2010]. It 2is assumed that they regulate gene expression notably via chromatin remodeling at their 3originate locus (in cis) and/or elsewhere in the genome (in trans). This property considerably 4increases the difficulty to identify their triggers and to understand their physiological roles. 5By RT-qPCR, we detected the highest expression level for NCRNA00201 in human 6cerebellum, making it a good candidate. Moreover, since our three deleted genes showed 7relatively high expression in the cerebellum when compared to other tissues, we might 8hypothesize that an epistatic effect of at least two genes from this locus could be responsible 9for our patients' phenotype. The lack of knowledge and the difficulty to interpret the variants 10identified in a non-coding gene explain why we did not sequence $N C R N A 00201$ in our series 11 of patients with ID. NCRNA00201 still remains a good candidate to explain ID but functional 12analyses are needed to clarify the implication of this gene in the phenotype.

13 Taken together, our aCGH, expression and sequencing data highlight a critical region 14containing three good candidate genes for non-syndromic ID and seizures. These results will 15be important for clinicians in genetic counseling.

16

\section{AKNOWLEDGMENTS}

18

19We are grateful to the patients and their families who participated in this study, to Rémi 20Houlgatte, Catherine Chevalier from Plateforme génomique intégrative de Nantes, to Jean 21Mosser from Biogenouest de Nantes, France, and to Lucie Tosca and Sophie Brisset from the 22cytogenetic laboratory, Hôpital Antoine Beclère. GT was supported by La Fondation pour la 23Recherche Médicale.

24

25CONFLICT OF INTEREST 
2The authors declare no conflict of interest.

3

\section{REFERENCES}

5

6Ballif BC, Rosenfeld JA, Traylor R, Theisen A, Bader PI, Ladda RL, Sell SL, Steinraths M, 7Surti U, McGuire M, Williams S, Farrell SA, Filiano J, Schnur RE, Coffey LB, Tervo RC, 8Stroud T, Marble M, Netzloff M, Hanson K, Aylsworth AS, Bamforth JS, Babu D, Niyazov 9DM, Ravnan JB, Schultz RA, Lamb AN, Torchia BS, Bejjani BA, Shaffer LG. 2011. High10resolution array $\mathrm{CGH}$ defines critical regions and candidate genes for microcephaly, 11 abnormalities of the corpus callosum, and seizure phenotypes in patients with microdeletions 12of 1q43q44. Hum Genet [Epub ahead of print].

13

14Bhalla K, Luo Y, Buchan T, Beachem MA, Guzauskas GF, Ladd S, Bratcher SJ, Schroer RJ, 15Balsamo J, DuPont BR, Lilien J, Srivastava AK. 2008. Alterations in CDH15 and KIRREL3 16in patients with mild to severe intellectual disability. Am J Hum Genet 83:703-13.

17

18Boland E, Clayton-Smith J, Woo VG, McKee S, Manson FD, Medne L, Zackai E, Swanson 19EA, Fitzpatrick D, Millen KJ, Sherr EH, Dobyns WB, Black GC. 2007. Mapping of deletion 20and translocation breakpoints in 1q44 implicates the serine/threonine kinase AKT3 in 21postnatal microcephaly and agenesis of the corpus callosum. Am J Hum Genet 81:292-303.

22

23Caliebe A, Kroes HY, van der Smagt JJ, Martin-Subero JI, Tönnies H, van 't Slot R, 24Nievelstein RA, Muhle H, Stephani U, Alfke K, Stefanova I, Hellenbroich Y, Gillessen25Kaesbach G, Hochstenbach R, Siebert R, Poot M. 2010. Four patients with speech delay, 
1seizures and variable corpus callosum thickness sharing a $0.440 \mathrm{Mb}$ deletion in region 1q44 2containing the HNRPU gene. Eur J Med Genet 53:179-85.

3

4Chelly J, Khelfaoui M, Francis F, Chérif B, Bienvenu T. 2006. Genetics and pathophysiology 5of mental retardation. Eur J Hum Genet 14:701-13.

6

7De Vries BB, Knight SJ, Homfray T, Smithson SF, Flint J, Winter RM. 2001. 8Submicroscopic subtelomeric 1qter deletions: a recognisable phenotype? J Med Genet 938:175-8.

10

11Dreyfuss G, Kim VN, Kataoka N. 2002. Messenger-RNA-binding proteins and the messages 12they carry. Nat Rev Mol Cell Biol 3:195-205.

13

14IHMC (International HapMap Consortium). 2005. A haplotype map of the human genome. 15Nature 437:1299-320.

16

17Kawano S, Miyaji M, Ichiyasu S, Tsutsui KM, Tsutsui K. 2010. Regulation of DNA 18Topoisomerase IIbeta through RNA-dependent association with heterogeneous nuclear 19ribonucleoprotein U (hnRNP U). J Biol Chem 285:26451-26460.

20

21Krecic AM, Swanson MS. 1999. hnRNP complexes: composition, structure, and function. 22Curr Opin Cell Biol 11:363-71.

23

24Livak KJ, Schmittgen TD. 2001. Analysis of relative gene expression data using real-time 25quantitative PCR and the 2(-Delta Delta C(T)) Method. Methods 25:402-8. 
2Matsuzaki H, Wang PH, Hu J, Rava R, Fu GK. 2009. High resolution discovery and 3 confirmation of copy number variants in 90 Yoruba Nigerians. Genome Biol 10:R125.

4

5Nagamani SC, Erez A, Bay C, Pettigrew A, Lalani SR, Herman K, Graham BH, Nowaczyk 6MJ, Proud M, Craigen WJ, Hopkins B, Kozel B, Plunkett K, Hixson P, Stankiewicz P, Patel 7A, Cheung SW. 2012. Delineation of a deletion region critical for corpus callosal 8abnormalities in chromosome 1q43-q44. Eur J Hum Genet 20:176-9.

9

10Qureshi IA, Mattick JS, Mehler MF. 2010. Long non-coding RNAs in nervous system 11 function and disease. Brain Res 18;1338:20-35.

12

13Roshon MJ, Ruley HE. 2005. Hypomorphic mutation in hnRNP U results in post14implantation lethality. Transgenic Res 14:179-192.

15

16van Bon BW, Koolen DA, Borgatti R, Magee A, Garcia-Minaur S, Rooms L, Reardon W, 17Zollino M, Bonaglia MC, De Gregori M, Novara F, Grasso R, Ciccone R, van Duyvenvoorde 18HA, Aalbers AM, Guerrini R, Fazzi E, Nillesen WM, McCullough S, Kant SG, Marcelis CL, 19Pfundt R, de Leeuw N, Smeets D, Sistermans EA, Wit JM, Hamel BC, Brunner HG, Kooy F, 20Zuffardi O, de Vries BB. 2008. Clinical and molecular characteristics of 1qter microdeletion 21syndrome: delineating a critical region for corpus callosum agenesis/hypogenesis. J Med 22Genet 45:346-54. 


\section{LEGENDS TO FIGURES}

3

4Figure 1. Facial phenotypes of six patients with interstitial 1q44 deletion showing non5 specific craniofacial anomalies.

6

7Figure 2. A. Map of the deletions in chromosomal band 1q44 identified by aCGH. Black 8horizontal bars indicate the deletions in the 11 patients with ID and seizures. Grey horizontal 9bar (CNP) indicates the deletion that we have identified in a healthy individual. The RefSeq 10 genes located in the genomic region are indicated. The vertical region shaded in red indicates 11 the smallest region of overlap (SRO) implicated in ID and seizures from our study; in yellow, 12the SRO implicated in microcephaly; in blue, the SRO implicated in corpus callosum 13abnormalities. B. Detailed map of the proposed critical region for ID and seizures, which 14contains three candidate genes: HNRNPU, FAM36A and NCRNA00201. The EFCAB2 gene 15 was considered as unlikely causative since we have identified it in a healthy individual. 16Horizontal red bars indicate the deletions reported in the Database of Genomic Variants 17(www.tcag.org). Three variants involving at least one of the three candidate genes (HNRNPU, $18 F A M 36 A$ and NCRNA00201) are reported in the Database of Genomic Variants have been 19identified in three HAPMAP individuals of Yoruba Nigerian origin [Matsuzaki et al., 2009]. 20 However, we obtained normal results with our targeted $60 \mathrm{~K}$ array, excluding a deletion in the $211 \mathrm{q} 44$ region in these individuals and, thus, demonstrating that the deletions identified by 22Matsuzaki et al. [2009] were false positive results. 
1Figure 3. Expression patterns of HNRNPU, FAM36A and NCRNA00201 in a panel of human 2tissues.

$3 \mathrm{cDNA}$ were obtained using the MMLV reverse transcriptase (Invitrogen) with random 4primers from $1 \mu \mathrm{g}$ of human total RNA of five adult and four fetal tissues. Real-time PCR 5was performed in triplicates using Takara SYBR premix on Light Cycler 480 (Roche 6diagnostics). The $\Delta \Delta \mathrm{Ct}$ method was used to assess expression level of three target genes 7HNRNPU, FAM36A and NCRNA00201 - relative to the expression level of the $\beta$-actin 8(ACTB) and cyclophilin E (PPIE) housekeeping genes. For a given target gene, the $\Delta \mathrm{Ct}$ of 9each tissue was compared to the median of the $\Delta \mathrm{Ct}$ of the 6 tissues analyzed. 
TABLE I. Clinical features and array CGH data of the 11 patients with 1q44 microdeletion 


\begin{tabular}{|c|c|c|c|c|c|c|c|c|c|c|c|c|}
\hline & $\begin{array}{l}\text { Patient } 1 \\
\end{array}$ & $\begin{array}{l}\text { Patient } 2 \\
\end{array}$ & $\begin{array}{l}\text { Patient } 3 \\
\end{array}$ & $\begin{array}{l}\text { Patient } 4 \\
\end{array}$ & Patient 5 & Patient 6 & $\begin{array}{l}\text { Patient } 7 \\
\end{array}$ & $\begin{array}{l}\text { Patient } 8 \\
\end{array}$ & $\begin{array}{l}\text { Patient } 9 \\
\end{array}$ & Patient 10 & Patient 11 & Total \\
\hline Current age (years) & $3^{10 / 12}$ & $5^{1 / 12}$ & $4^{6 / 12}$ & $6 / 12$ & $12^{9 / 12}$ & $2^{6 / 12}$ & $13^{6 / 12}$ & $10^{6 / 12}$ & 17 & $4^{10 / 12}$ & $9^{10 / 12}$ & \\
\hline $\begin{array}{l}\text { Coordinates of the deletions (in Mb using } \\
\text { hg19 genome build) }\end{array}$ & $243.1-245.4$ & $243.9-246.5$ & $244.3-245.1$ & $244.4-245.3$ & $244.4-245.6$ & $244.5-246.7$ & $244.5-245.4$ & $244.6-246.1$ & $244.7-245.4$ & $244.8-245.5$ & $244.9-246.3$ & \\
\hline $\begin{array}{l}\text { Size of the deletions 1q44 }(\mathrm{Mb}) \\
\text { Parental inheritance }\end{array}$ & $\begin{array}{c}2.26 \\
\text { de novo }\end{array}$ & $\begin{array}{c}2.56 \\
\text { de novo }\end{array}$ & $\begin{array}{l}0.79 \\
\text { de novo }\end{array}$ & $\begin{array}{l}0.90 \\
\text { de novo }\end{array}$ & $\begin{array}{c}1.16 \\
\text { de novo }\end{array}$ & $\begin{array}{c}2.19 \\
\text { de novo }\end{array}$ & $\begin{array}{c}0.89 \\
\text { de novo }\end{array}$ & $\begin{array}{c}1.5 \\
\text { Mother normal, } \\
\text { father NA }\end{array}$ & $\begin{array}{l}0.68 \\
\text { de novo }\end{array}$ & $\begin{array}{c}0.63 \\
\text { de novo }\end{array}$ & $\begin{array}{c}1.35 \\
\text { de novo }\end{array}$ & $10 / 11$ \\
\hline \multicolumn{13}{|l|}{ Distinctive facial features } \\
\hline hypertelorism & - & + & - & - & + & + & + & NA & - & - & - & $4 / 10$ \\
\hline bulbous nose & + & + & + & + & - & - & + & NA & - & - & - & $5 / 10$ \\
\hline philtrum flat/ absent cupidon bows & + & - & - & - & + & + & - & NA & + & - & + & $5 / 10$ \\
\hline thick lips & + & - & - & + & - & + & - & NA & - & - & + & $4 / 10$ \\
\hline abnormal ears & - & - & - & + & + & - & - & NA & - & + & + & $4 / 10$ \\
\hline flat occiput & - & + & - & - & - & - & - & NA & - & + & + & $3 / 10$ \\
\hline \multicolumn{13}{|l|}{ Measurement abnormalities (SD) } \\
\hline IUGR birth weight & -2 & -1 & -2 & +1 & NA & 0 & 0 & -1 & $-1,5$ & $-0,5$ & $+0,5$ & \\
\hline postnatal growth delay & -1 & -3 & -3 & -1 & $-1,8$ & $-2,5$ & $-0,5$ & $-1,5$ & 0 & $-2,5$ & $-0,8$ & \\
\hline OFC & -4 & -3 & $-2,6$ & -1 & $-0,5$ & $-1,2$ & -1 & 1,5 & 0 & 0 & -1 & \\
\hline BMI & +1 & +4 & +3 & NA & +4 & $+0,5$ & $+1,5$ & $+3,5$ & $+1,8$ & +4 & +4 & \\
\hline Strabismus & - & NA & + & NA & + & - & - & - & + & + & NA & $4 / 8$ \\
\hline Developmental delay/mental retardation & severe & severe & severe & severe & severe & moderate & severe & $\begin{array}{l}\text { moderate to } \\
\text { severe }\end{array}$ & severe & severe & severe & \\
\hline $\begin{array}{l}\text { age of the sitted station (years) } \\
\text { age of walk }\end{array}$ & $\begin{array}{l}3 \\
\text { not acquired }\end{array}$ & $\begin{array}{l}\text { NA } \\
5 \text { (with support) }\end{array}$ & $\underset{3^{10 / 12}}{\mathrm{NA}}$ & $\begin{array}{l}\text { NA } \\
\text { NA }\end{array}$ & $\begin{array}{l}\mathrm{NA} \\
3^{10 / 12}\end{array}$ & $\begin{array}{c}6 / 12 \\
2\end{array}$ & $\begin{array}{c}10 / 12 \\
1^{9 / 12}\end{array}$ & $\begin{array}{r}11 / 12 \\
1^{10 / 12}\end{array}$ & $\begin{array}{c}10 / 12 \\
2\end{array}$ & $\underset{4^{10 / 12}}{\mathrm{NA}}$ & $\begin{array}{c}10 / 12 \\
2\end{array}$ & \\
\hline no expressive speech & + & - & + & NA & - & - & + & - & + & - & + & $5 / 10$ \\
\hline hypotonia & + & NA & + & - & - & + & - & - & + & NA & - & $4 / 9$ \\
\hline stereotyped movements of the hands & + & - & + & - & - & - & + & - & + & + & - & $5 / 11$ \\
\hline sleep disorders & - & NA & - & NA & - & - & - & - & + & + & - & $2 / 9$ \\
\hline $\begin{array}{l}\text { autistic features and/or attention deficit } \\
\text { disorders }\end{array}$ & - & NA & - & NA & - & - & + & - & + & + & + & $4 / 9$ \\
\hline Epileptic seizures & + & + & + & + & + & + & + & + & + & + & + & $11 / 11$ \\
\hline Cerebral MRI & $\begin{array}{l}\text { generalised } \\
\text { atrophy, } \\
\text { moderate } \\
\text { micropolygyria }\end{array}$ & $\begin{array}{l}\text { micropolygyria, } \\
\text { delayed } \\
\text { myelinisation }\end{array}$ & normal & $\begin{array}{l}\text { Myelinisation } \\
\text { delay and } \\
\text { generalised } \\
\text { atrophy }\end{array}$ & normal & $\begin{array}{l}\text { small-sized } \\
\text { frontal angioma }\end{array}$ & $\begin{array}{l}\text { Cerebellar } \\
\text { hypoplasia }\end{array}$ & $\begin{array}{c}\text { moderate } \\
\text { cerebellar } \\
\text { hypoplasia }\end{array}$ & $\begin{array}{l}\text { delayed } \\
\text { myelinisation, } \\
\text { moderate } \\
\text { subcortical } \\
\text { atrophy }\end{array}$ & normal & $\begin{array}{l}\text { moderate } \\
\text { ventricular } \\
\text { dilatation }\end{array}$ & \\
\hline corpus callosum & normal & agenesis & normal & normal & normal & normal & normal & normal & normal & normal & normal & \\
\hline Other features and malformations & $\begin{array}{c}\text { spaced teeth, } \\
\text { sparse hair, } \\
\text { vertical striated } \\
\text { nails }\end{array}$ & $\begin{array}{l}\text { cardiopathy, } \\
\text { scoliosis, dry } \\
\text { skin, articular } \\
\text { hyperlaxity }\end{array}$ & $\begin{array}{l}\text { articular } \\
\text { hyperlaxity }\end{array}$ & $\begin{array}{l}\text { cryptorchidy, } \\
\text { mild nail } \\
\text { hypoplasia } \\
\text { fingers }\end{array}$ & $\begin{array}{c}\text { operated talipes } \\
\text { valgus and flat } \\
\text { feet }\end{array}$ & $\begin{array}{l}\text { clinodactyly of } \\
\text { fifth fingers, } \\
\text { butterfly } \\
\text { vertebra }\end{array}$ & erythroderma & cryptorchidy & $\begin{array}{l}\text { genu valgum, } \\
\text { valgus and flat } \\
\text { feet, } \\
\text { hyperlordosis, } \\
\text { articular } \\
\text { hyperlaxity }\end{array}$ & & $\begin{array}{l}\text { right renal } \\
\text { agenesis }\end{array}$ & \\
\hline
\end{tabular}


Supplementary TABLE I. Boundaries and sizes of the deletions identified by array CGH

\begin{tabular}{|c|c|c|c|c|c|c|c|c|c|c|}
\hline \multirow[t]{2}{*}{ Patient ID } & \multicolumn{2}{|c|}{ Last centromeric normal probe } & \multicolumn{2}{|c|}{ First centromeric deleted probe } & \multicolumn{2}{|c|}{ Last telomeric deleted probe } & \multicolumn{2}{|c|}{ First telomeric normal probe } & \multicolumn{2}{|c|}{ Size of the deletions } \\
\hline & $\begin{array}{c}\text { Agilent probe } \\
\text { number }\end{array}$ & $\begin{array}{l}\text { Genomic } \\
\text { position }\end{array}$ & $\begin{array}{c}\text { Agilent probe } \\
\text { number }\end{array}$ & $\begin{array}{l}\text { Genomic } \\
\text { position }\end{array}$ & $\begin{array}{c}\text { Agilent probe } \\
\text { number }\end{array}$ & $\begin{array}{l}\text { Genomic } \\
\text { position }\end{array}$ & $\begin{array}{c}\text { Agilent probe } \\
\text { number }\end{array}$ & $\begin{array}{l}\text { Genomic } \\
\text { position }\end{array}$ & $\begin{array}{c}\text { minimum } \\
\text { size }\end{array}$ & $\begin{array}{l}\text { maximum } \\
\text { size }\end{array}$ \\
\hline 1 & A_18_P10580799 & $\begin{array}{c}\text { chr1:24312716 } \\
2-243127221 \\
\end{array}$ & 18_P18165872 & $\begin{array}{c}\text { chr1:24316902 } \\
8-243169078 \\
\end{array}$ & 16 P1 & $\begin{array}{c}\text { chr1:24542780 } \\
9-245427868\end{array}$ & A 16 P5635 & \begin{tabular}{|c|} 
chr1:245428632- \\
245428691
\end{tabular} & 2258840 & 2301470 \\
\hline 2 & - & $\begin{array}{c}\text { chr1:24398142 } \\
9-243981487\end{array}$ & $P 5$ & $\begin{array}{c}\text { chr1:24398165 } \\
7-243981707\end{array}$ & $P_{2} \rightarrow>-1$ & $\begin{array}{c}\text { chr1:24655035 } \\
8-246550417\end{array}$ & 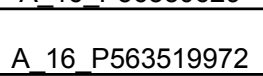 & \begin{tabular}{|c|} 
chr1:246550861- \\
246550920 \\
\end{tabular} & $\underline{0}$ & 33 \\
\hline 3 & 16_P15514696 & $\begin{array}{c}\text { chr1:24436896 } \\
8-244369027 \\
\end{array}$ & 16_P00291606 & $\begin{array}{c}\text { chr1:24436904 } \\
0-244369093 \\
\end{array}$ & A_16_P00292517 & $\begin{array}{c}\text { chr1:24516281 } \\
5-245162874 \\
\end{array}$ & A_16_P1551 & $\begin{array}{l}62911- \\
2970 \\
\end{array}$ & 793834 & 93943 \\
\hline 4 & A_16_P00291762 & $\begin{array}{c}\text { chr1:24 } \\
1-2444\end{array}$ & A_18_P18170664 & $\begin{array}{c}\text { chr1:2 } \\
4-24 \\
\end{array}$ & A_16_P563500560 & $\begin{array}{r}\text { chr1:2 } \\
8-24\end{array}$ & A_18_P18173616 & $\begin{array}{r}\text { chr1:2 } \\
245 \\
\end{array}$ & 908709 & 909427 \\
\hline 5 & A_18_P181717703 & $\begin{array}{c}\text { chr1:24 } \\
2-2444 \\
\end{array}$ & 18_P18171183 & $\begin{array}{r}\text { chr1:2 } \\
3-244 \\
\end{array}$ & 16_P00293234 & $\begin{array}{r}\text { chr1:2 } \\
6-245 \\
\end{array}$ & 50 & \begin{tabular}{|c|} 
chr1:245628202- \\
245628246 \\
\end{tabular} & 65 & 1165090 \\
\hline 6 & A_16_P15515033 & $\begin{array}{l}51166 \\
11723\end{array}$ & 16_P00291804 & $\begin{array}{c}\text { chr1:2 } \\
9-24\end{array}$ & 16 P00294898 & $\begin{array}{c}\text { chr1:24670789 } \\
3-246707952\end{array}$ & A_16_P15520201 & $\begin{array}{r}\text { chr1:24 } \\
2477\end{array}$ & 2195773 & 2196319 \\
\hline 7 & A_16_P00291835 & $\begin{array}{c}\text { chr1:2 } \\
7-24 \\
\end{array}$ & 16_P15515090 & $\begin{array}{r}\text { chr1: } \\
1-24\end{array}$ & A_16_P56350678 & $\begin{array}{l}546638 \\
66440 \\
\end{array}$ & A_16_P15516988 & \begin{tabular}{|c|} 
chr1:245466879- \\
245466938 \\
\end{tabular} & 891827 & 931192 \\
\hline 8 & A_16_P56349373 & $\begin{array}{r}\text { chr1:2 } \\
2-244 \\
\end{array}$ & P15515367 & $\begin{array}{c}\text { chr1:2 } \\
5-24 \\
\end{array}$ & 6547 & $\begin{array}{r}\text { chr1:2 } \\
8-24 \\
\end{array}$ & 723 & $\begin{array}{r}\text { chr1:24 } \\
2461 \\
\end{array}$ & 503132 & 504562 \\
\hline 9 & 92062 & $\begin{array}{c}\text { chr1:24 } \\
7-2447\end{array}$ & $16 \mathrm{POC}$ & $\begin{array}{r}\text { chr1:24 } \\
0-244 \\
\end{array}$ & 16_P56350651 & $\begin{array}{c}\text { chr1:24544326 } \\
2-245443321\end{array}$ & 929 & \begin{tabular}{|c|} 
chr1:245446121- \\
245446180
\end{tabular} & 677991 & 681244 \\
\hline 10 & A_18_P181724450 & $\begin{array}{c}\text { chr1:24489098 } \\
3-244891027\end{array}$ & 18 P18172462 & $\begin{array}{r}\text { chr1: } \\
7-24\end{array}$ & 18_P18175051 & $\begin{array}{c}\text { chr1:24552646 } \\
9-245527024\end{array}$ & A_16_P15517164 & $\begin{array}{c}\text { chr1:245527049- } \\
245527100\end{array}$ & 635907 & 636022 \\
\hline 11 & A $16 \_$P56350022 & $\begin{array}{r}\text { chr1: } \\
8-24\end{array}$ & A 16 P56350024 & $\begin{array}{r}\text { chr1: } \\
1-24 \\
\end{array}$ & A_18_P10588331 & $\begin{array}{r}\text { chr1: } \\
0-24\end{array}$ & A_18_P18177727 & $\begin{array}{l}32753- \\
812\end{array}$ & 1357948 & 1358234 \\
\hline CNP & A_18_P18171833 & $\begin{array}{c}\text { chr1:24519752 } \\
2-245197581\end{array}$ & A_16_P56350270 & $\begin{array}{c}\text { chr1:24519752 } \\
2-245197581\end{array}$ & A_16_P15517963 & $\begin{array}{c}\text { chr1:24582342 } \\
0-245823479\end{array}$ & A_16_P15517964 & \begin{tabular}{|c|} 
chr1:245823589- \\
245823648
\end{tabular} & 625957 & 626008 \\
\hline
\end{tabular}




\section{Figure 1}

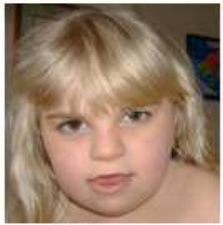

Patient 1

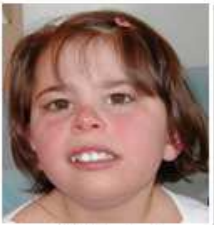

Patient 3

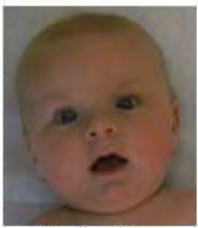

Patient 4

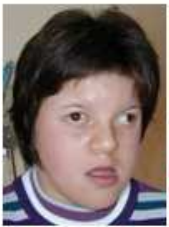

Patient 5

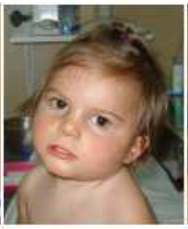

Patient 6

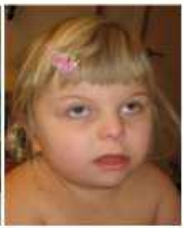

Patient 10 


\section{A}

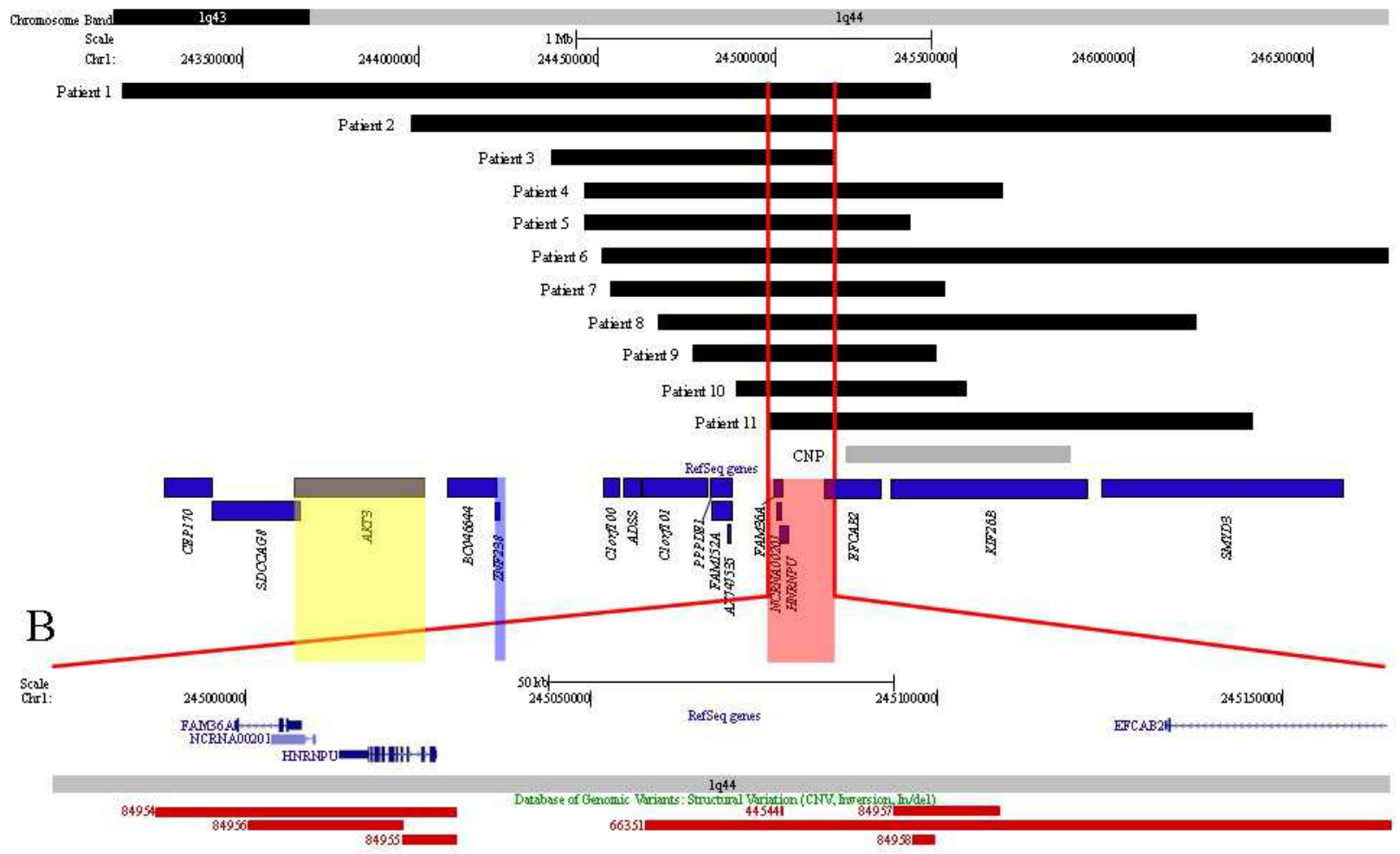


Figure 3

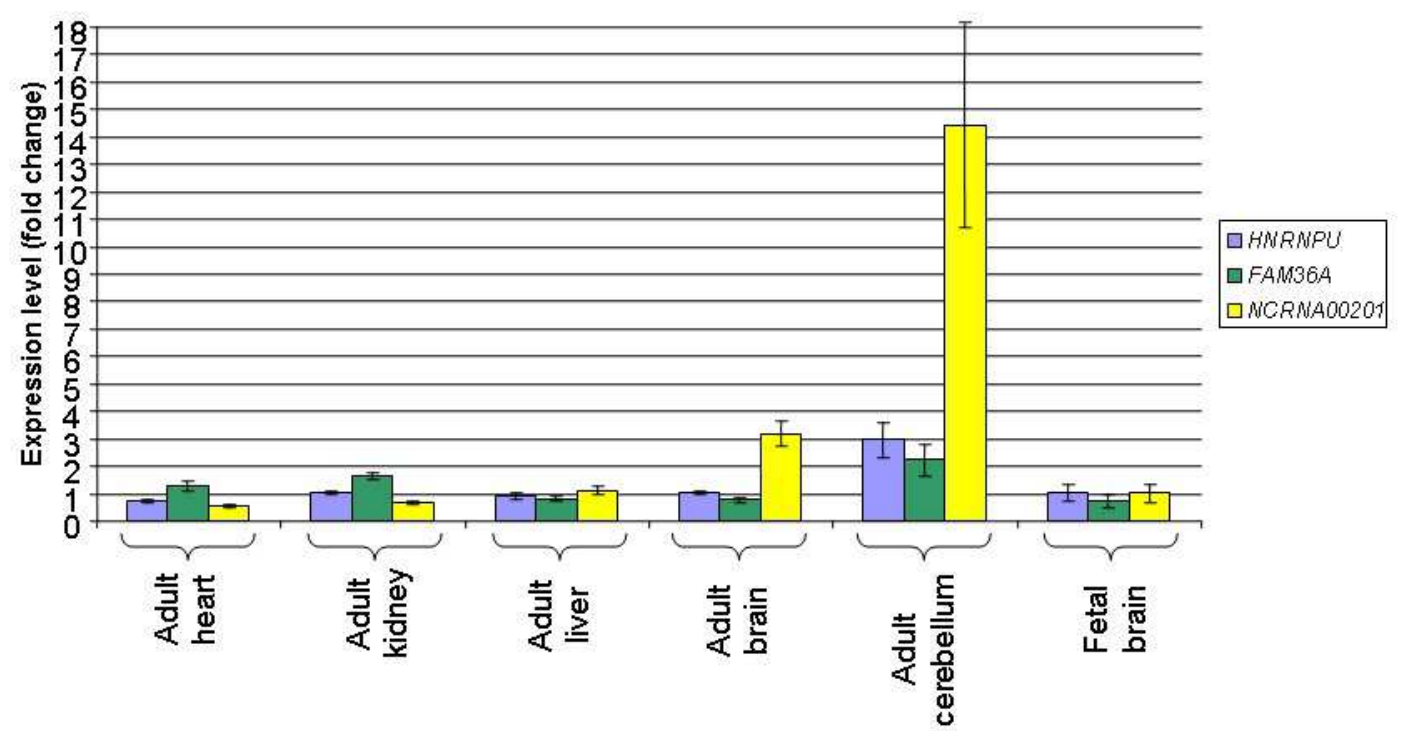

